\section{The relationship between low birth weight and exposure to inhalable particulate matter}

\author{
Relação entre baixo peso ao nascer e exposição ao \\ material particulado inalável
}

\author{
Relación entre el bajo peso al nacer y la exposición \\ a partículas inhalables
}

\author{
${ }^{1}$ Faculdade de Medicina, \\ Universidade de São Paulo, \\ São Paulo, Brasil. \\ 2 Divisão de Saúde do \\ Trabalhador e Meio \\ Ambiente, Prefeitura do \\ Município de São Bernardo \\ do Campo, São Bernardo do \\ Campo, Brasil. \\ 3 Programa de Pós-graduação \\ em Saúde Coletiva, \\ Universidade Católica de \\ Santos, Santos, Brasil. \\ Correspondence \\ L. C. Martins \\ Programa de Pós-graduação \\ em Saúde Coletiva, \\ Universidade Católica de \\ Santos. \\ Rua Carvalho de Mendonça \\ 144, sala 402, Santos, $S P$ \\ 11070-100, Brasil. \\ lourdesc@usp.br
}

\begin{abstract}
Atmospheric pollution is a global public health problem. The adverse effects of air pollution are strongly associated with respiratory and cardiovascular diseases and, to a lesser extent, with adverse pregnancy outcomes. This study analyzes the relationship between exposure to $P M_{10}$ and low birth weight in the city of Santo André, São Paulo State, Brazil. We included babies born to mothers resident in Santo André between 2000 and 2006. Data on daily PM 10 levels was obtained from the São Paulo State Environmental Agency. We performed descriptive analysis and logistic regressions. The prevalence rate of low birth weight was 5.9\%. There was a doseresponse relationship between $P M_{10}$ concentrations and low birth weight. Exposure to the highest quartile of $P M_{10}\left(37,50 \mu \mathrm{g} / \mathrm{m}^{3}\right)$ in the third trimester of pregnancy increased the risk of low birth weight by 26\% (OR: 1.26; 95\%CI: 1.14-1.40) when compared to the first quartile. The same effect was observed in the remaining trimesters. This effect was observed for ambient particle concentrations that met the current air quality standards.
\end{abstract}

Low Birth Weight Infant; Particulate Matter; Air Pollution; Logistic Models
Rodrigo Romão 1,2

Luiz Alberto Amador Pereira 1,3

Paulo Hilário Nascimento Saldiva 1

Patricia Matias Pinheiro 3

Alfésio Luiz Ferreira Braga 1,3

Lourdes Conceição Martins 3

\section{Resumo}

Em todo o mundo a poluição atmosférica é um problema de saúde pública. Os efeitos adversos relacionados aos poluentes atmosféricos estão fortemente associados com doenças respiratórias e cardiovasculares e, em menor grau, com os resultados adversos da gravidez. O objetivo do trabalho foi avaliar a relação entre $P M_{10}$ e baixo peso ao nascer no Município de Santo André, São Paulo, Brasil. Foram incluídos no estudo recém-nascidos de mães residentes em Santo André (2000-2006). A Agência Ambiental do Estado de São Paulo forneceu dados diários de $P M_{10}$. Realizou-se análise descritiva e de regressão logística. A prevalência de baixo peso ao nascer foi de 5,9\%. Observou-se uma relação dose-resposta entre as concentrações de $P M_{10}$ e baixo peso ao nascer. As concentrações de $P M_{10}$ no quartil mais alto $\left(37,50 \mu \mathrm{g} / \mathrm{m}^{3}\right)$ no terceiro trimestre gestacional aumentaram o risco de baixo peso ao nascer em 26\% (OR = 1,26; IC95\%: 1,14-1,40) quando comparadas com o primeiro quartil. O mesmo efeito foi observado nos demais trimestres. Esse efeito foi verificado mesmo com as concentrações de partículas dentro dos padrões de qualidade do ar.

Recém-Nascido de Baixo Peso; Material Particulado; Poluição do Ar; Modelos Logísticos 


\section{Introduction}

Air pollution principally affects the cardiovascular and respiratory systems and constitutes a worldwide public health problem. Motor vehicles are a major source of air pollution in urban areas. However, it is important to emphasize that in certain regions of the world biomass burning is also an important source of air pollution that causes adverse health effects 1,2 .

Low birth weight has been considered a leading indicator of morbidity and mortality in newborns and children worldwide for several decades. According to the World Health Organization, newborns weighing less than 2,500g are considered underweight ${ }^{3}$ and low birth weight is the single most important indicator of morbidity and mortality. In 1998 the Pan American Health Organization ${ }^{4}$ reported that the global frequency of low birth weight ranges from $3 \%$ to $43 \%$, illustrating the seriousness of this problem.

Risk factors for low birth weight include teenage pregnancy 5 , socio-economic differences 6 , prematurity, congenital malformations, advanced reproductive age and poor access to pre-natal care. A study conducted in the city of Goiania, State of Goiás, Brazil, also reported that the nutritional status of pregnant adolescents affects birth weight 7 .

Exposure to air pollution is also considered a risk factor for low birth weight and associations between air pollution and low birth weight have been observed in cities of different sizes $8,9,10,11,12$. A study conducted in Massachusetts (United States) between 1996 and 2002 found an association between exposure to traffic pollution and reduced birth weight, prematurity and social inequality 13 .

A literature review of ambient air pollution and pregnancy outcomes carried out by Srám et al. 14 found varying degrees of association between air pollution and intrauterine growth retardation, low birth weight, reproductive effects, premature birth and highlighted the relationship between exposure to particulate matter and death due to respiratory disease during the postneonatal period. However, Ritz et al. ${ }^{15}$ have suggested that the use of different criteria in studies of air pollution and birth outcomes hampers the differentiation between risk factors, reinforcing the need for a deeper knowledge of the underlying biological mechanisms of adverse pregnancy outcomes associated with air pollution.

The city of Santo André is situated in the metropolitan region of São Paulo, Brazil, and is affected by both traffic and industrial pollution. To the best of our knowledge, the affect of pollution on birth weight has yet to be investigated in this region and therefore this study aimed to evaluate the relationship between $\mathrm{PM}_{10}$ and low birth weight in Santo André

\section{Methods}

This is a longitudinal study using information from the Information System on Live Births (SINASC) of the Brazilian Ministry of Health. There were 63,818 live births to mothers resident in Santo Andre between January 1st 2000 and December 31st 2006. We selected all newborns with records of birth weight born after at least 37 completed weeks of pregnancy.

Santo André is located in the metropolitan region of São Paulo, has a population of 673,234 inhabitants (Brazilian Institute of Geography and Statistics - IBGE. http://www.ibge.gov.br, accessed on 20/Dec/2012) and covers an area of $175 \mathrm{~km}^{2}$. The city is a highly industrial area and has a large fleet of light and heavy motor vehicles. There are no regular biomass burning plants or thermoelectric power plants in this city.

Variables included date of birth, child's gender, birth weight, maternal marital status, level of education and age, type of pregnancy and delivery and number of prenatal consultations.

Data regarding 24-hour levels of $\mathrm{PM}_{10}$ (inhalable particulate matter that is less than $10 \mathrm{mi}-$ crons in diameter) was obtained from the São Paulo State Environmental Agency (CETESB) 16 The CETESB has two monitoring stations in Santo André. One is located downtown and the other is situated in the eastside of the city close to the Capuava Petrochemical pole. $\mathrm{PM}_{10}$ levels were used as a sole measure of air pollution due to the lack of comprehensive data regarding other pollutants such as $\mathrm{CO}$ and $\mathrm{O}_{3}$. Since $\mathrm{PM}_{10}$ records in both stations were highly correlated $(\mathrm{r}=0,89$; $\mathrm{p}<$ 0.01 ) we adopted the average of the two stations as being representative of air pollution levels.

A descriptive analysis was performed for each variable evaluated by this study. The test for the comparison of two proportions was used to compare categories. Birth weight was analyzed as a dichotomous variable (normal birth weight or low birth weight) using univariate logistic regression models to assess the relationship between the following variables: maternal age (between 20 and 34 years of age, under 20 years of age, and over 34 years of age), years of maternal schooling ( $\leq 6$ years and $\geq 7$ years), number of prenatal visits ( $\leq 6$ visits and $\geq 7$ visits), delivery (normal or caesarean), kind of pregnancy (single or multiple), marital status (married or unmarried), and child's gender. The variable years of maternal schooling was used as a proxy for maternal smoking 8,10,13,17. 
Multiple logistic regression of the $\mathrm{PM}_{10}$ quartiles and the variables with $\mathrm{p}$-values below 0.2 (maternal age, years of maternal schooling and number of prenatal visits) was performed. Only significant variables ( $p$-value $\leq 0.05$ ) were retained in the final model.

Three windows of exposure were defined (first, second and third trimester of pregnancy) based on the date of birth of each newborn estimated during pregnancy and average trimester exposure to $\mathrm{PM}_{10}$ was calculated for each trimester. The continuous variables considered by the logistic models were transformed into categorical variables (quartiles) 18,19.

Version 17.0 of the SPSS for Windows statistical package (SPSS Inc., Chicago, USA) was used for statistical analysis. The statistical significance level was set at $5 \%$.

\section{Results}

The initial sample of 63,818 live births between 2000 and 2006 was reduced to 57,392 (90\%) after excluding premature newborns and newborns where birth weight was not informed.

Table 1 presents the descriptive analysis of child's gender, type of delivery, birth weight, prenatal visits, maternal age, years of maternal schooling and marital status. The majority of live births were male $(p=0.05)$ and $61.4 \%$ of deliveries were cesarean $(p<0.001)$. The prevalence of underweight among newborns was $5.1 \%(\mathrm{p}<0.001)$. The majority of mothers attended seven or more prenatal consultations $(\mathrm{p}<0.001)$, were aged between 20 and 34 years, had completed over seven years of schooling $(\mathrm{p}<0.001)$ and were married or living in consensual union $(\mathrm{p}<0.001)$.

Table 2 presents a descriptive analysis of $\mathrm{PM}_{10}$ by trimester of pregnancy. It can be observed that average $\mathrm{PM}_{10}$ levels were similar in each semester, demonstrating that levels remained constant during the study period. $\mathrm{PM}_{10}$ levels remained well below the annual average standard of $150 \mu \mathrm{g} /$ $\mathrm{m}^{3}$ ) and maximum quarterly values. The average daily threshold limit for good air quality $(50 \mu \mathrm{g} /$ $\mathrm{m}^{3}$ ) was exceeded on seven days during the period studied.

Figure 1 shows the odds ratios (OR) and their respective $95 \%$ confidence intervals $(95 \% \mathrm{CI})$ for the association between low birth weight and exposure to $\mathrm{PM}_{10}$ by pregnancy trimester and exposure quartile. This final model was adjusted for maternal age, years of maternal schooling and number of prenatal visits.

A significant association was found between risk of low birth weight and exposure to the third and fourth $\mathrm{PM}_{10}$ quartiles during the first and sec- ond pregnancy trimester, while during the third trimester this risk was associated with exposure to the second, third and fourth $\mathrm{PM}_{10}$ quartiles. There was a dose-dependent effect in all pregnancy trimesters (Figure 1).

The ORs for the other variables included in the final model are shown in Table 3. It can be observed that risk of low birth weight was also associated with the variables maternal age, years of maternal schooling and number of prenatal visits.

\section{Discussion}

The results of the present study indicate an association between risk of low birth weight and exposure to ambient levels of $\mathrm{PM}_{10}$. This effect was dose-dependent and was observed for all pregnancy exposure windows, reinforcing the concept that air pollution influences pregnancy outcomes.

A study conducted in Rio de Janeiro reported that low birth weight was significantly associated with exposure to sulfur dioxide $\left(\mathrm{SO}_{2}\right)$ during the third pregnancy trimester (95\%CI: 1.0161.301) 10. In addition, in a study of a sample of 179,460 births, Gouveia et al. 8 found an association between low birth weight and exposure to $\mathrm{PM}_{10}$ and CO.

Similar associations between risk of low birth weight and exposure to other air pollutants have been found in different regions of the world. In Georgia (United States) for example an increased risk of low birth weight and exposure to $\mathrm{PM}_{10}$ was found in preterm births 20 , while a study in California (United States) reported an increased risk $(27 \%)$ of preterm birth and excess of low birth weight (36\%) associated with exposure to $\mathrm{PM}_{10}$ during the first trimester 21 . Another study in California reported an association between exposure to ozone $\left(\mathrm{O}_{3}\right)$ in the second and third trimesters and to $\mathrm{CO}$ in the first trimester and reduced birth weight 22. In Vancouver (Canada), a cohort study of 70,249 live births between 1999 and 2002 found an association between gestational age, premature birth and low birth weight and different forms of exposure to traffic pollution, including low exposure to low levels of pollution 23.

This study shows that exposure to $\mathrm{PM}_{10}$ is an important risk factor for low birth weight. $\mathrm{PM}_{10}$ consists of a mixture of organic and inorganic substances, including metals and secondary aerosols. In addition, $\mathrm{PM}_{10}$ levels are strongly correlated with concentrations of other primary gaseous pollutants. Polycyclic aromatic hydrocarbons (PAH) have been shown to be associated 
Table 1

Descriptive analysis of the main variables included in the study $(n=57,392)$

\begin{tabular}{|c|c|c|c|}
\hline Variables & $\mathrm{n}$ & $\%$ & p-value \\
\hline \multicolumn{4}{|l|}{ Sex of newborn } \\
\hline Male & 29,206 & 50.9 & 0.05 \\
\hline Female & 28,186 & 49.1 & \\
\hline \multicolumn{4}{|l|}{ Delivery } \\
\hline Vaginal & 22,062 & 38.5 & $<0.001$ \\
\hline Cesarean & 35,253 & 61.5 & \\
\hline \multicolumn{4}{|l|}{ Birth weight } \\
\hline Low & 2,944 & 5.1 & $<0.001$ \\
\hline Normal & 54,448 & 94.9 & \\
\hline \multicolumn{4}{|l|}{ Prenatal visits } \\
\hline 6 visits or under & 17,333 & 30.8 & $<0.001$ \\
\hline 7 visits or over & 38,964 & 69.2 & \\
\hline \multicolumn{4}{|l|}{ Maternal age (years) } \\
\hline 20 to 34 & 42,166 & 73.5 & $<0.001$ * \\
\hline Under 20 & 7,994 & 13.9 & \\
\hline Over 34 & 7,232 & 12.6 & \\
\hline \multicolumn{4}{|c|}{ Years of maternal schooling } \\
\hline Six years or under & 17,609 & 31.6 & $<0.001$ \\
\hline Seven years or over & 38,167 & 68.4 & \\
\hline Marital status & & & $<0.001$ ** \\
\hline Single & 18,654 & 33.1 & \\
\hline Married & 36,850 & 65.4 & \\
\hline Widow & 161 & 0.2 & \\
\hline Separated & 706 & 1.3 & \\
\hline
\end{tabular}

* 20 to 34 years vs. others;

** Married vs. others.

Table 2

Descriptive analysis of average levels of $\mathrm{PM}_{10}$ per trimester by pregnancy trimester.

\begin{tabular}{lccc}
\hline $\mathrm{PM}_{10}$ (variables) & \multicolumn{2}{c}{ Pregnancy trimesters } \\
& First & Second & Third \\
\hline Mean $\pm \mathrm{SD}$ & $36.82 \pm 9.13$ & $36.54 \pm 9.04$ & $35.70 \pm 8.06$ \\
Minimum-maximum & $22.74-65.55$ & $22.74-65.55$ & $22.74-55.95$ \\
\hline
\end{tabular}

SD: standard deviation

with fetal growth problems in Cracow (Poland) and New York City (United States), particularly among Afro-Americans 24. A study in Sydney (Australia) showed that low birth weight was associated with exposure to $\mathrm{CO}$ and nitrogen dioxide $\left(\mathrm{NO}_{2}\right)$ in the second and third trimesters of pregnancy and with exposure to $\mathrm{PM}_{10}$ in the second trimester 25. Research in Massachusetts and Connecticut (United States) showed an association between low birth weight and exposure to $\mathrm{PM}_{10}$ (third trimester), $\mathrm{CO}$ (first and third trimesters), $\mathrm{NO}_{2}$ and $\mathrm{SO}_{2}$ (first trimester) and $\mathrm{PM}_{2,5}$ (second and third trimesters). The same study found an apparently higher risk of low birth weight in children born to black mothers exposed to fine-mode aerosols $\left(\mathrm{PM}_{2.5}\right)$ 26. Nasci- 
Figure 1

Odds ratio $(\mathrm{OR})$ for low birth weight by pregnancy trimester and $\mathrm{PM}_{10}$ quartiles.

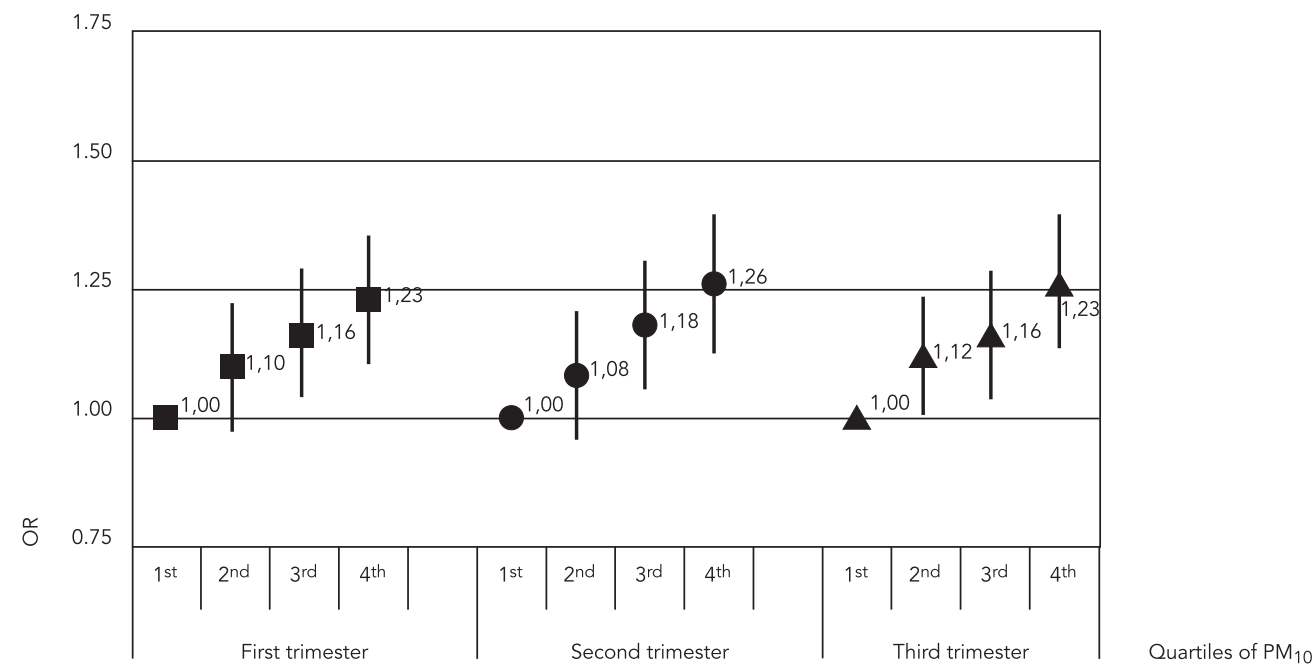

Table 3

Odds ratio (OR) for low birth weight by pregnancy trimester and $\mathrm{PM}_{10}$ quartiles, maternal age, years of maternal schooling and number of prenatal visits.

\begin{tabular}{lll}
\hline & OR & $95 \% \mathrm{Cl}$ \\
\hline $\begin{array}{l}\text { Maternal age (years) } \\
20-34\end{array}$ & 1.00 & $1.07-1.32$ \\
$<20$ & 1.19 & $1.14-1.41$ \\
$>34$ & 1.27 & $1.09-1.28$ \\
Years of maternal schooling (years) & 1.00 & $1.05-1.25$ \\
7 or over & 1.18 & \\
$\quad$ or under & 1.00 & \\
Number of prenatal visits & 1.15 & \\
7 or more & & \\
6 or less & & \\
\hline
\end{tabular}

95\% Cl: $95 \%$ confidence interval.

mento \& Moreira 9 concluded that sulfur dioxide $\left(\mathrm{SO}_{2}\right)$ and ozone $\left(\mathrm{O}_{3}\right)$ were risk factors for low birth weight in the city of São José dos Campos (Brazil).

In contrast to the study carried out by Gouveia et al. ${ }^{8}$, which found an association between low birth weight and exposure to $\mathrm{PM}_{10}$ in the first trimester, our study observed an association in all trimesters. Other studies conducted in
Brazil have shown the effects of other pollutants such as $\mathrm{SO}_{2}, \mathrm{CO}, \mathrm{O}_{3}$ and $\mathrm{NO}_{2}$ on low birth weight outcomes.

It is important to note that the association between low birth weight and exposure to $\mathrm{PM}_{10}$ was significant even after controlling for confounding and relevant variables such as maternal age, years of maternal schooling and number of prenatal visits and exclusion of preterm newborns, 
supporting the idea that the effects of air pollution on pregnancy are causal.

Medeiros et al. 27 reviewed the possible pathogenic mechanisms by which exposure to air pollution adversely affects pregnancy outcomes. The rate of fetal weight gain is greatest between the 28th and 37th weeks of pregnancy. Placental HCL stimulates the dose-dependent release of adrenocorticotropic hormone (ACTH) that induces fetal maturation in the third trimester, thus promoting weight gain. A series of studies performed by the authors on rodents exposed to ambient levels of air pollution showed both low birth weights and reduced placental weights in animals exposed to air pollution. This and other studies show that it is plausible that placenta underdevelopment plays a role in determining low birth weight outcomes associated with pollution exposure $28,29,30,31$.

Other possible mechanisms should also be investigated to understand how exposure to air pollution adversely affects birth weight. Kannan et al. 32 studied the relationship between maternal nutrition and exposure to atmospheric particulate matter and highlighted cardiovascular oxidative stress, coagulation, pulmonary inflammation, placental endothelial function and hemodynamic responses as plausible biological mechanisms. Finally, a possible relationship between exposure to air pollution and maternal socioeconomic status as a risk factor ${ }^{6}$ should not be disregarded.
One of the limitations of this study lies in the difficulties involved in accurately measuring individual $\mathrm{PM}_{10}$ exposure levels due to differences in proximity of individuals' homes to sources of pollution and movement in and out of high pollution zones, particularly during the first and second trimester of pregnancy. Although this situation could be partially improved by increasing the number of monitoring stations in the study area, the only way of fully solving this measurement problem would be to use individual monitors which is logistically impossible given the size of the sample.

The pregnancy trimester was used based on others studies and given that these periods comprise important windows of exposure during gestation.

Data regarding other individual characteristics associated with low birth weight such as dietary habits, active or passive smoking during pregnancy, maternal weight before pregnancy, maternal morbidity and occupational exposure was not available. However, these individual risk factors are not considered confounding factors that could cause a bias in the relationship between exposure to air pollution and low birth weight because they vary regardless of pollution levels 10,33.

\section{Conclusions}

Our results confirm that the adverse effects of air pollution go beyond cardiorespiratory diseases. Air pollution significantly influences pregnancy outcomes by increasing the risk of low birth weight. 


\section{Resumen}

La contaminación del aire en todo el mundo es un problema de salud pública. Los efectos adversos relacionados con los contaminantes del aire están fuertemente asociados con enfermedades respiratorias y cardiovasculares, pero en menor medida con los resultados adversos del embarazo. En este estudió se evaluó la relación entre $P M_{10}$ y bajo peso al nacer en el municipio de Santo André, São Paulo, Brasil. Se incluyeron en el estudio los recién nacidos de madres residentes en Santo André (2000-2006). La Agencia Ambiental del Estado de São Paulo informó de los índices diarios de $P M_{10}$. Además, se realizó un análisis descriptivo y por regresión logística. La prevalencia de bajo peso al nacer fue de un 5,9\%. Hubo una relación dosis-respuesta entre las concentraciones de $P M_{10}$ y bajo peso al nacer. Las concentraciones de $P M_{10}$ en el cuartil más alto $\left(37,50 \mu \mathrm{g} / \mathrm{m}^{3}\right)$ en el tercer trimestre aumentaban el riesgo gestacional de bajo peso al nacer en un 26\% (OR = 1,26; IC95\%: 1,14$1,40)$, en comparación con el primer cuartil. El mismo efecto se observó en los trimestres restantes. Este efecto fue observado incluso en partículas con concentraciones que están dentro de los estándares del aire.

Recién Nacido de Bajo Peso; Material Particulado; Contaminación del Aire; Modelos Logísticos

\section{References}

1. Olmo NRS, Saldiva PHN, Braga ALF, Lin CA, Santos UP, Pereira LAA. A review of low-level air pollution and adverse effects on human health: implications for epidemiological studies and public policy. Clinics 2011; 66:681-90.

2. Martins LC, Pereira LAA, Lin CA, Santos UP, Priolli G, Luiz OC, et al. The effects of air pollution on cardiovascular diseases: lag structures. Rev Saúde Pública 2006; 40:677-83.

3. World Health Organization. The incidence of low birth weight: a critical review of available information. World Health Stat Q 1980; 33:197-224.

4. Organización Panamericana de la Salud. La salud en las Américas. v. I. Washington DC: Organización Panamericana de la Salud; 1998; (Publicación Científica, 569).

5. Aquino-Cunha M, Queiroz-Andrade M, TavaresNeto J, Andrade T. Pregnancy in adolescence: relation to low birth weight. Rev Bras Ginecol Obstet 2002; 24:513-9.

\section{Contributors}

R. Romão contributed to data collection and analysis and drafting of the manuscript. L. A. A. Pereira and A. L. F. Braga contributed to data collection and drafting of the manuscript. P. M. Pinheiro contributed to drafting of the manuscript. P. H. N. Saldiva contributed to the revision of the manuscript. L. C. Martins contributed to study design, data analysis and drafting of the manuscript.

\section{Acknowledgements}

We are grateful to the Environmental Epidemiology Study Group, Laboratory of Experimental Air Pollution, the Faculty of Medical Sciences of the University of São Paulo, CNPq, the São Paulo State Environmental Agency, and FAPESP.
6. Andrade CLT, Szwarcwald CL, Gama SGN, Leal MC. Desigualdades sócio-econômicas do baixo peso ao nascer e da mortalidade perinatal no Município do Rio de Janeiro, 2001. Cad Saúde Pública 2004; 20 Suppl 1:S44-51.

7. Guerra AFFS, Heyde MED, Mulinari RA. Inpacto do estado nutricional no peso ao nascer em recémnascidos de gestantes adolescentes. Rev Bras Ginecol Obstet 2007; 29:126-33.

8. Gouveia N, Bremner SA, Novaes HMD. Association between ambient air pollution and birth weight in São Paulo, Brazil. J Epidemiol Community Health 2004; 58:11-7.

9. Nascimento LFC, Moreira DA. Are environmental pollutants risk factors for low birth weight? Cad Saúde Pública 2009; 25:1791-6.

10. Junger WL, Ponce de Leon A. Poluição do ar e baixo peso ao nascer no Município do Rio de Janeiro, Brasil, 2002. Cad Saúde Pública 2007; 23 Suppl 4:S588-98. 
11. Stieb DM, Chen L, Eshoul M, Judek S. Ambient air pollution, birth weight and preterm birth: a systematic review and meta-analysis. Environ Res 2012; 117:100-11.

12. Shah PS, Balkhair T; Knowledge Synthesis Groupon Determinants of Preterm/LBM Births. Air pollution and birth outcomes: a systematic review. Environ Int 2011; 37:498-516.

13. Zeka A, Melly SJ, Schwartz J. The effects of socioeconomic status and indices of physical environment on reduced birth weight and preterms births in Eastern Massachusetts. Environ Health 2008; 7:60.

14. Srám RJ, Binková B, Dejmek J, Bobak M. Ambient air pollution and pregnancy outcomes: a review of the literature. Environ Health Perspect 2005; 113:375-82.

15. Ritz B, Wilhelm M. Ambient air pollution and adverse birth outcomes: methodologic issues in an emerging field. Basic Clin Pharmacol Toxicol 2008; 102:182-90.

16. Companhia Ambiental do Estado de São Paulo. Relatório de qualidade do ar, 2008. http://www. cetesb.sp.gov.br/ar/qualidade-do-ar/31-publica coes-e-relatorios (accessed on 15/Sep/2009).

17. Galão AO, Soder AS, Gerhardt M, Faertes TH, Krüger MS, Pereira DF, et al. Efeitos do fumo materno durante a gestação e complicações perinatais. Rev HCPA \& Fac Med Univ Fed Rio Gd do Sul 2009; 29:218-24.

18. Callegari-Jacques SM. Bioestatística: princípios e aplicações. Porto Alegre: Artmed Editora; 2003.

19. Kleinbaum DG, Kupper LL, Muller KE, Nizam A. Applied regression analysis and other multivariable methods. Belmont: Duxbury Press; 1998.

20. Rogers JF, Dunlop AL. Air pollution and very low birth weight infants: a target population? Pediatrics 2006; 118:156-64.

21. Wilhelm M, Ritz B. Local variations in CO and particulate air pollution and adverse birth outcomes in Los Angeles County, California, USA. Environ Health Perspect 2005; 113:1212-21.

22. Salam MT, Millstein J, Li Y, Lurmann FW, Margolis HG, Gilliland FD. Birth outcomes and prenatal exposure to ozone, carbon monoxide, and particulate matter: results from the children's health study. Environ Health Perspect 2005; 113:1638-44.

23. Brauer M, Lencar C, Tamburic L, Koehoom M, Demers P, Karr C. A cohort study of traffic-related air pollution impacts of birth outcomes. Environ Health Perspect 2008; 116:680-6.
24. Choi H, Jedrychowski W, Spengler J, Camann DE, Whyatt RM, Rauh V, et al. International studies of prenatal exposure to polycyclic aromatic hydrocarbons and fetal growth. Environ Health Perspect 2006; 114:1744-50.

25. Mannes T, Jalaludin B, Morgan G, Lincoln D, Sheppeard V, Corbett S. Impact of ambient air pollution on birth weight in Sidney, Australia. Occup Environ Med 2005; 62:524-30.

26. Bell M, Ebisu K, Belanger K. Ambient air pollution and low birth weight in Connecticut and Massachussets. Environ Health Perspect 2007; 115: 1118-24.

27. Medeiros A, Gouveia N. Relação entre baixo peso ao nascer e a poluição do ar no município de São Paulo. Rev Saúde Pública 2005; 39:965-72.

28. Linton EA, Perkins AV, Woods RJ, Eben F, Wolfe $\mathrm{CD}$, Behan DP, et al. Corticotropin releasing hormonebinding protein (CRH-BP): plasma levels decrease during the third trimester of normal human pregnancy. J Clin Endocrinol Metab 1993; 76:260-2.

29. Veras MM, Damaceno-Rodrigues NR, Caldini EG, Maciel Ribeiro AA, Mayhew TM, Saldiva PH, et al. Particulate urban air pollution affects the functional morphology of mouse placenta. Biol Reprod 2008; 79:578-84.

30. Rocha E, Silva IR, Lichtenfels AJ, Pereira LAA, Saldiva PH. Effects of ambient levels of air pollution generated by traffic on birth and placental weights in mice. Fertil Steril 2008; 90:1921-4.

31. Mohallem SV, de Araújo Lobo DJ, Pesquero CR, Assunção JV, de Andre PA, Saldiva PH, et al. De creased fertility in mice exposed to environmental air pollution in the city of Sao Paulo. Environ Res 2005; 98:196-202.

32. Kannan S, Misra DP, Dvonch JT, Krishnakumar A. Exposição à matéria particulada aérea e efeitos pe rinatais adversos: referencial mecanístico biologicamente plausível para exploração de potenciais. Ciênc Saúde Coletiva 2007; 12:1591-602.

33. Ha EH, Hong YC, Lee BE, Woo BH, Schwartz J, Christiani DC. Is air pollution a risk factor for low birth weight in Seoul? Epidemiology 2001; 12:643-8

Submitted on 14/Oct/2012

Final version resubmitted on 16/Jan/2013

Approved on 22/Jan/2013 